\title{
Andrew D. Morris, Colonial Project, National Game: A History of Baseball in Taiwan
}

Berkeley and Los Angeles, University of California Press, 2010, 271 pp.

\section{Jérôme Soldani}

Translator. N. Jayaram

\section{CpenEdition}

\section{Journals}

Electronic version

URL: http://journals.openedition.org/chinaperspectives/5679

DOI: $10.4000 /$ chinaperspectives. 5679

ISSN: 1996-4617

\section{Publisher}

Centre d'étude français sur la Chine contemporaine

Printed version

Date of publication: 1 October 2011

Number of pages: $92-94$

ISSN: 2070-3449

\section{Electronic reference}

Jérôme Soldani, «Andrew D. Morris, Colonial Project, National Game: A History of Baseball in Taiwan », China Perspectives [Online], 2011/3 | 2011, Online since 30 June 2011, connection on 24 September 2020. URL : http://journals.openedition.org/chinaperspectives/5679; DOI : https://doi.org/10.4000/ chinaperspectives.5679

This text was automatically generated on 24 September 2020.

(c) All rights reserved 


\section{Andrew D. Morris, Colonial Project, National Game: A History of Baseball in Taiwan}

Berkeley and Los Angeles, University of California Press, 2010, 271 pp.

Jérôme Soldani

Translation : N. Jayaram

1 American historian Andrew D. Morris, who has already published a thesis on physical culture(tiyu) under the Republic of China, ${ }^{1}$ now offers us the first social science work in a non-Chinese text specifically focusing on Taiwan's "national sport" (guoqiu) - baseball. Colonial Project, National Game (2010), was preceded in 2007 by Taiwanese scholar Yu Jun-wei's Playing in Isolation. ${ }^{2}$ But Yu's approach was more that of a chronicler. He was strongest in denouncing the tricks and tactics worn threadbare in defence of national honour. The work had much to commend itself in terms of documentation and restoration of some historical facts.

2 Scholarly interest in baseball was late in coming to Taiwan. It is only since the

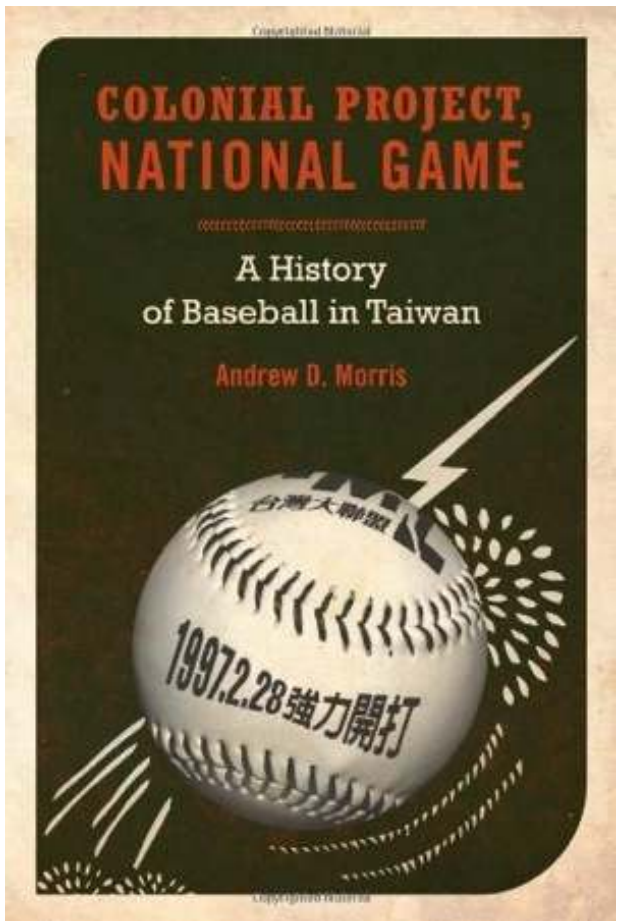
mid-1990s that Masters-level papers and theses have focused on it. A handful of Taiwanese researchers then began specialising in the history of baseball in Taiwan, ${ }^{3}$ and have more recently carried out sociological investigations, especially among the aborigines, who have taken to it with gusto. ${ }^{4}$ 
3 Despite the rising number of monographs on Taiwan, often of exemplary quality, sports are often overlooked, or at best marginalised, in accounts and analyses. This is all the more surprising given baseball's hold on Taiwan's daily life and media, its use in metaphors and symbols mobilised by the insular political world, or even in major celebrations such as the harvest festivals of some aborigine groups. However, this disdain for sports as an academic subject is not unique to Taiwan. Academics often fail to see links with local cultural tradition and dismiss them as a sub-product of modernity or even as "sub-culture" or part of what is increasingly deemed "popular culture." An outstanding quality of Andrew Morris's thesis is that it accords baseball the place it deserves in Taiwan's history and in scholarly research.

The book is divided into six chapters set out in chronological order, tracing the link between baseball and major political changes that have influenced its fortunes on the island over the past century. Morris's thesis relies greatly on working with archives and press reports, enriched by - rare and often exclusive - direct interviews, and above all on a fine analysis of Taiwanese films and documentaries on the "national sport."

Chapter 1 covers the island's Japanese era from 1895 to the 1920s, when the Japanese imported baseball to Taiwan for their own recreation and their children's training. In fact, it seems that for a long time, the Japanese denied Taiwanese from all walks of life any access to baseball. They themselves had played it only since the $1870 \mathrm{~s}$ and considered baseball a mark of their cultural flowering, fearing that the Taiwanese might use the sport to resist Japanese might on their own ground. For the Taiwanese, it was more about gaining a modicum of recognition as equals (p.13). From this standpoint, the Japanese behaved no better than the British in India with cricket. Drawing heavily on rare and mainly Japanese printed sources, Morris and most Taiwanese historians fail to consider the eventualdiffusion of baseball, or games derived from it, among local people outside of the official circuits closed to them. A focus on those games might have given us a glimpse of the conditions under which the sport was adopted by the islanders outside of the colonial policy of assimilation (dōka) in the 1920s. ${ }^{5}$ However, Morris shows that such exchanges between the Taiwanese and the colonisers took place even before this relaxed era, despite much contemporary talk of a certain initial defiance on the locals' part as regards such sports (p. 15).

6 Chapter 2 concentrates on the 1931-1945 period. Although better documented than the previous chapter, it lacks information on the war period. It deals at length with the story of a team from the Agriculture and Forestry School at Chiayi, known by the Japanese name Kanō and made up of Japanese players and Aborigines as well as Han Taiwanese (pp. 31-44). Morris documents its use by the colonial authorities to promote an image of interethnic harmony only one year after the Musha (Wushe in Chinese) massacre of $1930 .{ }^{6}$ The Kanō case is relatively marginal, but it generally served as a model for training future generations of players and for the peaceful coexistence between the island's disparate populations. This supposed idyll was to be re-invoked by pro-independence supporters decades later (p. 52).

7 Chapter 3 focuses on the sea change that followed in the period from the Kuomintang's 1945 seizure of power to 1967 . The Nationalist authorities initially viewed baseball as a scar left by Japanese colonisation, but came to claim it as a symbol of "Free China." Its rules were translated from Japanese into Mandarin. Baseball training was included in the nationalist physical cultureprogramme. Although the KMT regime was unable to extricate Taiwanese baseball from its Japanese roots, it nevertheless played on popular 
passion and local players' talent to stoke nationalist sentiment and ensure a place in the sun for Taiwan in the international sporting arena. Meanwhile, Morris notes that basketball, favoured by Mainlanders and devoid of colonial trappings, was promoted during sporting contacts with communist countries during the Cold War. That was especially so with mainland China. Basketball thus received much state funding (p. 63). He also stresses that baseball in Taiwan is bound up with colonial heritage and nationalist, anti-Japanese ideology (p.67). To this must be added "Taiwanese" or "local" influences, as players have long claimed the sport as their own, if only through the use of the Hokkien dialect.

8 Chapters 4 and 5 are devoted to the international exploits of Taiwan's student teams in the 1970s and 1980s, a time of Taipei's increasing isolation in the global political scene. Their victories, acclaimed as major triumphs by the Nationalist government, were also claimed by the pro-independence opposition eager to establish whether they were more "Chinese" or "Taiwanese." But this dispute between the two political forces ought not to be read as a clear dichotomy among the Taiwanese. Their view of baseball and its history charts a course between the two, and their conception veers as much towards one side as the other, often concurrently. Another case studied at length (pp. 81-92) is that of the Hungyeh Elementary School team in a Bunun village in Taitung District, which vanquished a Japanese team in a tournament in Taiwan in 1968. The exploit, turned into a legend despite some obvious irregularities, was another instance of the Nationalist policy of assimilating aboriginal minorities through sport. This challenge to Japanese in a climate of nationalist fervour might have coincided with Taiwan's economic take-off and led to other transformations in baseball.

9 The biggest among them was the emergence of one, then two, national professional leagues by the early 1990s. This is covered in the last chapter in a rather pessimistic and at times too dismissive tone, harping on recurring disappointments in a professional milieu tainted by match-fixing scandals and weighed down by the predominance of imported players. The sport fell victim to the success of a capitalist consumption society and the rise of the depoliticised individual, all of this leading to deserted stands of a sport historically marked by identity questions. Morris also shows - citing multi-lingual songs, Chinese transcriptions of foreign players' names and references to Taiwanese daily life - the extent to which baseball's professionalisation had led to its reappropriation by combining US and Japanese models at the crossroads of "Chinese" and "Taiwanese" influences (pp. 131-135). Baseball was that bound up in a "glocalisation" process that Morris frequently evokes. Quoting Aviad Raz, he defines it as the tension between global cultural production and its local acquisition (p. 9).

The author could be criticised for focusing excessively on the political dimensions of baseball in Taiwan. But it is a defensible choice and one to which the book is not limited, as the previous example shows. He must be commended for having gone beyond a strictly chronological history and for taking interest in socio-cultural mechanisms underlying actual representations of baseball in Taiwan. However, there is much less about the way the game is played. Throughout the book, Morris evokes numerous concepts borrowed especially from postcolonial theories. As he himself has stressed, he set out to show that Taiwanese baseball's history constitutes a major path towards a general understanding of the Taiwanese context (p. 149). The book may well be said to have achieved its aims. It opens many paths for reflection to those who would wish to undertake research on sports, in Taiwan or elsewhere, and offers indispensable 
elements of knowledge and analyses to those intending to include baseball in their future studies of Taiwan.

\section{NOTES}

1. Andrew D. Morris, Marrow of the Nation: A History of Sport and Physical Culture in Republican China, Berkeley, University of California Press, 2004.

2. Yu Jun-wei, Playing in Isolation: A History of Baseball in Taiwan, Lincoln, University of Nebraska Press, 2007.

3. Hsieh Shih-yuan, Hsieh chia-fen (eds.), Taiwan bangqiu yibai nian (Hundred years of baseball in Taiwan), Taipei, Guoshi, 2003

4. Lin Wen-lan, Bangqiu zuowei "yuan /yuan meng jieti": Jiaoyu tizhi, wenhua chuangsheng yu shehui jiexu fanyan (Indigenous baseball dreams: The educational regime, cultural production, and reproduction of social hierarchies), PhD thesis, Taipei, National Taiwan University, 2010.

5. Jérôme Soldani, "Why do the Taiwanese play baseball? Diachronic study of a successfuldiffusion," Ethnologie française, vol. XLI, no. 4, 2011, pp. 677-689.

6. On 27 October 1930, Taiwanese Aborigines killed 134 Japanese - men, women, and children during a sporting event for children in Musha Village (Nantou District), leading to bloody reprisals by the Japanese colonisers.

\section{AUTHORS}

\section{JÉRÔME SOLDANI}

He is pursuing his $\mathrm{PhD}$ in anthropology at Université de Provence (Aix-en-Provence) / IDEMEC

(CNRS, UMR 6591). 